\title{
A HERMENÊUTICA JURÍDICA EM HANS KELSEN E A CRIMINALIZAÇÃO DA HOMOFOBIA E DA TRANSFOBIA ${ }^{1}$
}

\author{
THE LEGAL HERMENEUTICS IN HANS KELSEN AND THE CRIMINALIZATION \\ OF HOMOPHOBIA AND TRANSPHOBIA
}

\author{
PENETRACIÓN DE LA PERSONALIDAD JURÍDICA BAJO LA ÓPTICA DEL \\ ANÁLISIS ECONÓMICO DEL DERECHO
}

\author{
SAMUEL MENDONÇA \\ http://orcid.org/0000-0002-2918-0952 / http://lattes.cnpq.br/6369572439782922 / samuelms@gmail.com \\ Pontifícia Universidade Católica de Campinas \\ Campinas, SP, Brasil.
}

LUIZ FELIPE MENDES JULIANO

http://orcid.org/0000-0003-3388-9419 / http://lattes.cnpq.br/4266882343861331 / Ifmendes98@gmail.com Pontifícia Universidade Católica de Campinas

Campinas, SP, Brasil.

\begin{abstract}
RESUMO
A presente pesquisa tem como objeto de estudo o julgamento do Supremo Tribunal Federal sobre a criminalização da homofobia e da transfobia, sendo feita uma análise desse caso a partir da hermenêutica jurídica em Hans Kelsen. Para essa empreitada, o método é a pesquisa bibliográfica. 0 primeiro momento dessa pesquisa constitui-se de revisão de literatura em bases nacionais e internacionais sobre o tema. Além disso, também é contemplado o estudo de livros de Kelsen e de seus principais comentadores nacionais, em especial, Fábio Ulhoa Coelho e Tercio Sampaio Ferraz Junior. Já o outro momento da pesquisa bibliográfica se dá com a análise jurisprudencial, o estudo de caso, focalizando no referido julgamento em particular. Com a análise de todos esses materiais, é possível formular a pergunta que ensejou a investigação: há elementos da hermenêutica jurídica em Kelsen que expliquem o julgamento do Supremo Tribunal Federal acerca da criminalização da homofobia e da transfobia? Então, tomando por base os textos analisados, permite-se apontar, enquanto resultados obtidos, uma resposta positiva.
\end{abstract}

Palavras-chave: Hans Kelsen; Hermenêutica Jurídica; Homofobia; Supremo Tribunal Federal; Transfobia.

\begin{abstract}
This research has as object of study, in light of the legal hermeneutics in Hans Kelsen, the judgment of the Direct Action of Unconstitutionality for Omission 26 and Writ of Injunction 4733 that dealt with the criminalization of homophobia and transphobia in the Supreme Federal Court. The first moment of this research takes place with reviewing the literature in national and international research platforms. Furthermore, Kelsen's books and his main national commentators are also studied, especially Fábio Ulhoa Coelho and Tercio Sampaio Ferraz Júnior. The second moment of bibliographical research is a case law analysis, a case study focusing in that specific judgment. With the analysis of all these works it is possible to formulate the question that inspired the inquiry: are there elements of Kelsenian legal hermeneutics that explains the judgment of the Supreme Federal Court concerning the criminalization of homophobia and transphobia? Therefore, taking as base the analyzed texts, it is possible to point out an affirmative response from the obtained results.
\end{abstract}

Keywords: Hans Kelsen; Legal Hermeneutics; Homophobia, Supreme Federal Court; Transphobia.

\footnotetext{
${ }^{1}$ Pesquisa financiada pelo CNPq por meio do Processo 311111/2017-3, Bolsa de Produtividade em Pesquisa e Bolsa Fapic Reitoria da PUC Campinas.
} 


\section{RESUMEN}

La presente pesquisa tiene como objetivo de estudio el juicio del Supremo Tribunal Federal de Brasil acerca de la criminalización de la homofobia y transfobia, siendo hecha un análisis de este caso a partir de la hermenéutica legal en Hans Kelsen. Para este empeño, el método es la pesquisa bibliográfica. El primer momento de la pesquisa consiste en una revisión de literatura en bases nacionales e internacionales acerca del tema. Además, también es contemplado el estudio de libros de Kelsen y de sus principales comentadores nacionales, en especial, Fabio Ulhoa Coelho y Tercio Sampaio Ferraz Junior. Ya el otro momento de la pesquisa bibliográfica se da por medio de un análisis jurisprudencial, el estudio de caso, focalizando en el referido juicio en particular. Con el análisis de todos estos materiales, fue posible formular la pregunta que influyó la investigación: ¿hay elementos de la hermenéutica legal en Kelsen que explican lo juicio del Supremo Tribunal Federal acerca de la criminalización de la homofobia y de la transfobia? Entonces, llevando por base los textos analizados, es permitido apuntar, en relación a resultados obtenidos, una respuesta positiva.

Palabras-clave: Hans Kelsen; Hermenéutica Legal; Homofobia; Supremo Tribunal Federal; Transfobia.

\section{SUMÁRIO}

INTRODUÇÃO, 1 A HERMENÊUTICA JURÍDICA EM HANS KELSEN, 2 O JULGAMENTO DA CRIMINALIZAÇÃO DA HOMOFOBIA E DA TRANSFOBIA NO SUPREMO TRIBUNAL FEDERAL, 3 O JULGAMENTO À LUZ DA HERMENÊUTICA JURÍDICA KELSENIANA, CONCLUSÃO, REFERÊNCIAS.

\section{INTRODUÇÃO}

Este ensaio tem como tema o julgamento do Supremo Tribunal Federal acerca da criminalização da homofobia e da transfobia, sendo feita uma análise a partir da hermenêutica jurídica de Hans Kelsen². Mas, para a delimitação do objeto de estudo, é importante que se explique, primeiro, a metodologia que aqui se emprega.

Do ponto de vista do método, partiu-se de uma revisão de literatura nas bases Biblioteca Digital de Teses e Dissertações (BDTD) e na Scientific Eletronic Library Online (SciELO). Na primeira base, sob os descritores "Hermenêutica Jurídica”, "Hans Kelsen" e "Supremo Tribunal Federal", todos combinados, foram encontrados apenas dois resultados. Já na base SciELO, sob a combinação dos referidos três descritores, nada foi encontrado.

Devido à escassez de trabalhos sobre o tema nessas bases, foi necessário realizar também a revisão no Portal de Periódicos CAPES. Nele, sob dois primeiros descritores foram encontrados oitenta e oito trabalhos; sob o segundo e terceiro descritores, noventa e cinco escritos; e, por fim, sob o primeiro e o terceiro descritores, cento e cinquenta e três trabalhos. Aliado a tudo isso, abarcando também a pesquisa bibliográfica, houve o estudo de livros de Hans

\footnotetext{
${ }^{2}$ KELSEN, Hans. Teoria pura do direito. 6. ed. São Paulo: Martins Fontes, 1998. p. 387.
} 
Kelsen ${ }^{3}$ e de seus principais comentadores em âmbito nacional, destacando-se Tercio Sampaio Ferraz Junior ${ }^{4}$ e Fábio Ulhoa Coelho ${ }^{5}$.

Diante desse cenário, foi verificada não só a magnitude do pensamento de Hans Kelsen, mas também que a pesquisa jurisprudencial e o estudo de casos do Supremo Tribunal Federal são necessários para que a ciência jurídica avance. Não por outro motivo, o outro momento da metodologia se deu com a análise jurisprudencial, o estudo de caso.

A escolha do julgamento da criminalização da homofobia e da transfobia - Ação Direta de Inconstitucionalidade por Omissão (ADO) $26^{6}$ e Mandado de Injunção (MI) 47337 - deu-se em virtude dos fatores atualidade e relevância. A atualidade se faz presente, uma vez que o julgamento dessas ações no Supremo foi retomado e concluído em 13 de junho de 2019.

A relevância desse caso, por sua vez, é demonstrada na medida em que as discussões acerca da criminalização da homofobia e da transfobia são válidas e merecem atenção, seja da comunidade acadêmica, seja, do judiciário ou, sobretudo, do legislativo, o que se espelha, no presente caso, pela declaração da mora inconstitucional e pela equiparação temporária das práticas de homotransfobia à prática de racismo. Daí a delimitação do objeto de estudo deste artigo.

Como todo clássico, a Teoria Pura do Direito ${ }^{8}$ apresenta um leque praticamente infinito de pontos que poderiam ser objetos de investigação. Outrossim, os temas da homofobia e da transfobia no Brasil são vastíssimos e inviáveis de serem tratados por completo dentro das fronteiras deste artigo. Não por menos é que se fez um recorte, restringindo a presente análise ao julgamento da $\operatorname{ADO} 26^{9}$ e do $M I 4733^{10}$, tudo à luz da hermenêutica em Kelsen.

${ }^{3}$ KELSEN, Hans. Teoria geral das normas. Porto Alegre: Sergio Fabris, 1986. KELSEN, Hans. Teoria pura do direito. 6. ed. São Paulo: Martins Fontes, 1998. KELSEN, Hans. 0 que é a justiça? São Paulo: Martins Fontes, 2001.

${ }^{4}$ FERRAZ JR, Tercio Sampaio. Introdução ao estudo do direito: técnica, decisão, dominação. 8. ed. São Paulo: Atlas, 2015.

${ }^{5}$ COELHO, Fábio Ulhoa. Para entender Kelsen. São Paulo: Saraiva, 2012.

${ }^{6}$ BRASIL. Supremo Tribunal Federal. Ação Direta de Inconstitucionalidade por Omissão $n^{\circ}$ 26. Partido Popular Socialista. Relator: Ministro Celso de Mello. Disponível em: http://portal.stf.jus.br/processos/detalhe.asp?incidente=4515053. Acesso em: 12 jul. 2019.

${ }_{7}$ BRASIL. Supremo Tribunal Federal. Mandado de Injunção 4733. Associação Brasileira de Gays, Lésbicas e Transgêneros - ABGLT. Relator: Ministro Edson Fachin. Disponível em: https: / / portal.stf.jus.br/processos/detalhe.asp?incidente=4239576. Acesso em 13 de jul. de 2019.

${ }^{8}$ KELSEN, Hans. Teoria pura do direito. 6. ed. São Paulo: Martins Fontes, 1998.

9 BRASIL. Supremo Tribunal Federal. Ação Direta de Inconstitucionalidade por Omissão $n^{\circ}$ 26. Partido Popular Socialista. Relator: Ministro Celso de Mello. Disponível em: http://portal.stf.jus.br/processos/detalhe.asp?incidente=4515053. Acesso em: 12 jul. 2019. 
A partir desse recorte é que foi possível formular a pergunta que deu margem a esta investigação: há elementos da hermenêutica jurídica em Kelsen que expliquem o julgamento do Supremo Tribunal Federal acerca da criminalização da homofobia e da transfobia? Neste sentido, apresenta-se, enquanto resultados obtidos, que há sim elementos da hermenêutica jurídica kelseniana nesse julgamento.

É interessante notar que os cursos de graduação e também os cursos de mestrado e doutorado dos programas de pós-graduação em Direito brasileiros têm sido aprimorados, seja pela exigência de explicitação metodológica nas investigações, seja pela natureza da área que afirma a formação crítica como base na formação de operadores de direito. Estudos ${ }^{11}$ têm demonstrado a necessidade de aprimoramento contínuo da educação jurídica que, embora não seja objeto desta pesquisa, a articulação entre um determinado julgamento com base teórica consolidada do Direito, no caso Hans Kelsen, revela a singularidade e importância do manuscrito que poderá estimular outros pesquisadores a realizar tarefas de interpretação com as ferramentas da ciência jurídica.

Então, do ponto de vista formal, o artigo está organizado em três momentos. No primeiro, esboça-se a hermenêutica jurídica, conforme a exposição magistral contida na Teoria Pura do Direito ${ }^{12}$. Já no segundo momento, analisa-se o julgamento da criminalização da homotransfobia no Supremo Tribunal Federal. Ao final, no terceiro e último momento, há a explicação do caso de acordo com os elementos da hermenêutica kelseniana, articulando teoria e prática.

\footnotetext{
${ }^{10}$ BRASIL. Supremo Tribunal Federal. Mandado de Injunção 4733. Associação Brasileira de Gays, Lésbicas e Transgêneros - ABGLT. Relator: Ministro Edson Fachin. Disponível em: https://portal.stf.jus.br/processos/detalhe.asp?incidente=4239576. Acesso em 13 de jul. de 2019.

11 GASPAR, Renata Alvares; MENDONÇA, Samuel. O DIPR - Direito Internacional Privado e a Educação Jurídica: um diálogo essencial. Revista Eletrônica do Curso de Direito da UFSM, Santa Maria, RS, v. 13, n. 1 , p. 1-19, maio 2018. ISSN 1981-3694. Disponível em:
} https://periodicos.ufsm.br/revistadireito/article/view/27249. Acesso em: 14 jul. 2019.

MENDONCA, Samuel; ADAID, Felipe Alves Pereira. Tendências teóricas sobre o Ensino Jurídico entre 2004 e 2014: busca pela formação crítica. Rev. Direito GV, São Paulo, v. 14, n. 3, p. 818-846, set. 2018. Disponível em http://dx.doi.org/10.1590/2317-6172201831. Acesso em 13 de jul. de 2019.

12 KELSEN, Hans. Teoria pura do direito. 6. ed. São Paulo: Martins Fontes, 1998. p. 387. 


\section{A HERMENÊUTICA JURÍDICA EM HANS KELSEN}

Em meados do século $X X$, Hans Kelsen apresenta um rigoroso e exigente projeto de purificar a ciência jurídica de todas e quaisquer ideologias, a Teoria Pura do Direito ${ }^{13}$. Nesse livro, o autor constrói um estudo acerca do fenômeno jurídico procedendo com o máximo de objetividade e exatidão possíveis ${ }^{14}$, uma vez que consciente da especificidade de seu objeto, as normas jurídicas positivas. Conforme o dizer de Kelsen: “Na afirmação evidente de que o objeto da ciência jurídica é o Direito, está contida a afirmação - menos evidente - de que são as normas jurídicas o objeto da ciência jurídica”15. Daí, inclusive, o próprio título do livro:

Quando a si própria se designa como "pura" teoria do Direito, isto significa que ela se propõe garantir um conhecimento apenas dirigido ao Direito e excluir deste conhecimento tudo quanto não pertença ao seu objeto, tudo quanto não se possa, rigorosamente, determinar como Direito. Quer isto dizer que ela pretende libertar a ciência jurídica de todos os elementos que the são estranhos. Esse é o seu princípio metodológico fundamental. ${ }^{16}$

Desde logo, é essencial que se esclareça que não é que o Direito, enquanto fato social, seja neutro, posto que ele conteria, ao menos, os valores por ocasião da produção e da aplicação das normas jurídicas. Em verdade, neutra é (ou deveria ser) a ciência do Direito, a qual apresenta uma tendência anti-ideológica ${ }^{17}$. Anti-ideológica, aqui, no sentido de repudiar fortemente qualquer questionamento externo ao campo da ciência e à especificidade de seu objeto. Então, “pura”, na verdade, se refere à “Teoria”, e não ao “Direito”:

Basicamente, o projeto "teoria pura do direito" requer atenção ao fato de que a palavra "pura" se refere à "teoria", e não ao "direito". Porque o "direito", bem sabe Kelsen, por ser composto de normas, traduz-se em cenário de disputa política e da afirmação de valores. Ou seja, o papel da ciência jurídica é diverso do da política ${ }^{18}$.

\footnotetext{
${ }^{13}$ KELSEN, Hans. Teoria pura do direito. 6. ed. São Paulo: Martins Fontes, 1998.

${ }^{14}$ KELSEN, Hans. Teoria pura do direito. 6. ed. São Paulo: Martins Fontes, 1998. p. XI.

${ }^{15}$ KELSEN, Hans. Teoria pura do direito. 6. ed. São Paulo: Martins Fontes, 1998. p. 79.

${ }^{16}$ KELSEN, Hans. Teoria pura do direito. 6. ed. São Paulo: Martins Fontes, 1998. p. 1.

${ }^{17}$ KELSEN, Hans. Teoria pura do direito. 6. ed. São Paulo: Martins Fontes, 1998. p. 118.

${ }^{18}$ SGARBI, Adrian. 0 mundo de Kelsen. São Paulo: Marcial Pons, 2019. p. 11.
} 
Assim, seguindo um ideal de pureza metodológica com rigor é que seria possível uma genuína e "[...] verdadeira ciência do direito"19, cujo grau de confiabilidade lembraria, até mesmo, as ciências naturais ${ }^{20}$. Dessa forma, é o princípio metodológico fundamental, que rege a ciência purificada, aquele que tem o condão de legitimá-la e separá-la de toda e qualquer contaminação subjetiva e ideológica, fazendo isso em prol da verdade:

É uma lei vital de todo conhecimento puro que ele seja desenvolvido por si só. Essa lei aplica-se especialmente às ciências sociais, pois quando essas ciências são colocadas a serviço da política elas não mais servem o ideal de verdade objetiva, mas devem tornar-se uma ideologia de poder ${ }^{21}$.

Ainda nos dizeres de Kelsen ${ }^{22}$, não é que o Direito não comporte análises estruturais a partir da sociologia, da história ou da filosofia. Tais análises são importantes e essenciais à compreensão completa do fenômeno jurídico. Contudo, tomando por base suas considerações sobre objeto e o método da ciência do Direito, Kelsen é responsável por afastar o jusnaturalismo como forma de se encarar o fenômeno jurídico.

Se, até então, o estudo do Direito tinha o viés de uma metafísica, calcada em preceitos naturais, absolutos, universais e atemporais, com Kelsen, o fenômeno jurídico é encarado como um construído humano e seu estudo assume as roupagens da ciência, com pretensões de objetividade e exatidão ${ }^{23}$. Neste sentido, é possível dizer que a doutrina jusnaturalista não se mantém perante o tribunal da ciência ${ }^{24}$. Por isso mesmo, não só a grande motivação de Kelsen era elevar o estudo do Direito ao grau de cientificidade ${ }^{25}$, como também é, certamente, uma de suas grandes contribuições.

De outra banda, o princípio metodológico fundamental se perfaz, igualmente, como um dos maiores limites à ciência jurídica. Isso exatamente porque as questões sociológicas, históricas e filosóficas estão além de sua alçada. Todas elas, já que metajurídicas, tentam, de alguma forma, (des)legitimar o Direito positivo tomando por base juízos morais altamente relativos e subjetivos, os quais não só não compõem o objeto de estudo da ciência jurídica, como também a contaminam.

\footnotetext{
${ }^{19}$ KELSEN, Hans. Teoria pura do direito. 6. ed. São Paulo: Martins Fontes, 1998. p. 118

${ }^{20}$ SGARBI, Adrian. 0 mundo de Kelsen. São Paulo: Marcial Pons, 2019. p. 11.

${ }^{21}$ KELSEN, Hans. 0 que é a justiça? São Paulo: Martins Fontes, 2001. p. 93

22 KELSEN, Hans. 0 que é a justiça? São Paulo: Martins Fontes, 2001. p. 291.

23 KELSEN, Hans. Teoria pura do direito. 6. ed. São Paulo: Martins Fontes, 1998. p. XI.

${ }^{24}$ KELSEN, Hans. O que é a justiça? São Paulo: Martins Fontes, 2001. p. 137.

${ }^{25}$ COELHO, Fábio Ulhoa. Para entender Kelsen. São Paulo: Saraiva, 2012. p. 23.
} 
Para o autor, apenas em uma concepção jusnaturalista é que seria possível admitir valores absolutos e que comporiam a essência do estudo do Direito ${ }^{26}$. Na verdade, é precisamente por essas múltiplas questões morais terem caráter muito relativo e subjetivo que elas não têm a aptidão de fornecerem respaldo a uma análise científica do Direito ${ }^{27}$. Quer isso dizer que o estudo da validade das normas jurídicas não está vinculado ao estudo dos preceitos morais.

Isso seria incompatível com o propósito da Teoria Pura, isto é, com seu princípio metodológico fundamental, com suas pretensões de universalidade e com sua missão de apenas conhecer e descrever especificamente seu objeto, ao invés de aprová-lo ou não, o que caberia, de fato, ao campo político. Com isso, o cientista do Direito, não podendo se identificar com qualquer valor, nem mesmo com o valor jurídico por ele descrito ${ }^{28}$, acaba por ficar impedido de se engajar com uma postura crítica e fica refém do arbítrio do criador e do aplicador da norma jurídica.

Com efeito, a cientificidade do Direito, nos termos kelsenianos, tem um custo. Este é a limitação do papel do jurista científico, que pode apenas conhecer e descrever as possibilidades agasalhadas pela norma jurídica, sem, contudo, apontar qual deveria ser a opção a ser adotada do ponto de vista da justiça, que é um valor moral. Desse modo, e fazendo alusão ao pensamento wittgeinsteiniano: “[...] o que a ciência jurídica não pode descrever, deve omitir"29. Assim é que, fiel a um ideal de pureza metodológica, o cientista renuncia à avaliação da justiça, relegando-a ao campo político, muito embora seja uma questão tão cara à orientação humana:

Ou seja, Kelsen propõe que, uma vez demonstrada a impossibilidade de se superar cientificamente a multiplicidade de sistemas morais, então o mais correto para a doutrina é renunciar à avaliação da justiça ou injustiça da ordem jurídica [...]. Em suma, para ele, o que não se pode falar sobre o direito positivo, com consistência científica, deve-se calar ${ }^{30}$.

Ocorre que seguir rigorosamente o princípio metodológico fundamental traz alguns desdobramentos importantes na Teoria de Kelsen, presentes, inclusive, e, especialmente, na

\footnotetext{
${ }^{26}$ KELSEN, Hans. O que é a justiça? São Paulo: Martins Fontes, 2001. p. 161

${ }^{27}$ KELSEN, Hans. Teoria pura do direito. 6. ed. São Paulo: Martins Fontes, 1998. p. 76.

${ }^{28}$ KELSEN, Hans. Teoria pura do direito. 6. ed. São Paulo: Martins Fontes, 1998. p. 77.

${ }^{29}$ FERRAZ JR, Tercio Sampaio. Introdução ao estudo do direito: técnica, decisão, dominação. 8. ed. São Paulo: Atlas, 2015. p. 219.

${ }^{30}$ COELHO, Fábio Ulhoa. Para entender Kelsen. São Paulo: Saraiva, 2012. p. 87.
} 
parte sobre hermenêutica jurídica. Porém, antes, fazem-se necessários alguns apontamentos acerca da pirâmide kelseniana, ponto relevante para o entendimento da questão hermenêutica.

Estudando o sistema jurídico, o autor afirma que este pode ser tomado em dois momentos $^{31}$. 0 primeiro deles é o momento estático, entendido como conjunto de normas jurídicas em vigor, a partir de categorias tais como sanção, dever jurídico, direito subjetivo, capacidade de exercício, capacidade, relação e sujeito jurídicos. Por outro lado, o sistema entendido em seu momento dinâmico diz respeito à criação e à aplicação do Direito.

Dessa feita, perquirir acerca do fundamento de validade das normas jurídicas se situa nesse momento ${ }^{32}$. $\mathrm{E}$, ao perquirir cientificamente sobre o fundamento de validade das normas jurídicas, Kelsen teve que se ater ao princípio metodológico fundamental. Ou seja, o autor não poderia fundamentar a norma jurídica senão a partir de outra norma, pois, caso contrário, não se ateria à especificidade de seu objeto de estudo.

Por certo, se o que permite que uma norma seja considerada como jurídica é outra norma, tida como superior, esta fornecendo àquela a validade jurídica, então o sistema é organizado não como um apanhado de normas em um mesmo nível, mas como um conjunto em relação de hierarquia: “A ordem jurídica não é um sistema de normas jurídicas ordenadas no mesmo plano, situadas umas ao lado das outras, mas é uma construção escalonada de diferentes camadas ou níveis de normas jurídicas" ${ }^{33}$. Eis a consagrada pirâmide kelseniana. Aqui, a ideia central é, precisamente, a de que o fundamento de validade de uma norma de quilate inferior é aquela de quilate superior:

O fundamento de validade de uma norma apenas pode ser a validade de outra norma. Uma norma que representa o fundamento de validade de uma outra norma é figurativamente designada como norma superior, por confronto com uma norma que é, em relação a ela, norma inferior ${ }^{34}$

Entretanto, a representação do sistema jurídico não poderia remeter ao infinito. Atingindo o ápice da pirâmide normativa, a primeira Constituição histórica, como é possível que essa norma jurídica receba seu fundamento de validade? A saída de Kelsen, atentando-se, como de costume, ao seu princípio metodológico fundamental, que não permite legitimar o Direito por fatores ideológicos, é um pressuposto lógico-formal, denominado norma fundamental:

\footnotetext{
31 KELSEN, Hans. Teoria pura do direito. 6. ed. São Paulo: Martins Fontes, 1998. p. 80.

32 KELSEN, Hans. Teoria pura do direito. 6. ed. São Paulo: Martins Fontes, 1998. p. 215.

${ }^{33}$ KELSEN, Hans. Teoria pura do direito. 6. ed. São Paulo: Martins Fontes, 1998. p. 247.

${ }^{34}$ KELSEN, Hans. Teoria pura do direito. 6. ed. São Paulo: Martins Fontes, 1998. p. 215.
} 


\begin{abstract}
Tratando-se de uma Constituição que é historicamente a primeira, tal só é possível se pressupusermos que os indivíduos se devem conduzir de acordo com o sentido subjetivo deste ato, que devem ser executados atos de coerção sob pressupostos fixados e pela forma estabelecida nas normas que caracterizamos como Constituição, quer dizer, desde que pressuponhamos uma norma por força da qual o ato a interpretar como ato constituinte seja de considerar como um ato criador de normas objetivamente válidas e os indivíduos que põem este ato como autoridade constitucional. Esta norma é [...] a norma fundamental de uma ordem jurídica estadual. Esta não é uma norma posta através de um ato jurídico positivo, mas - como revela uma análise dos nossos juízos jurídicos - uma norma pressuposta sempre que $\mathrm{o}$ ato em questão seja de entender como ato constituinte, como ato criador da Constituição, e os atos postos com fundamento nesta Constituição como atos jurídicos. Constatar esta pressuposição é uma função essencial da ciência jurídica. Em tal pressuposição reside o último fundamento de validade da ordem jurídica, fundamento esse que, no entanto, pela sua mesma essência, é um fundamento tão-somente condicional e, neste sentido, hipotético ${ }^{35}$.
\end{abstract}

Neste sentido, o que é capaz de amarrar todo o sistema jurídico, o que fundamenta a unidade de uma pluralidade de normas, é uma norma hipotética, meramente pensada, pressuposta, a norma fundamental ${ }^{36}$. Tal norma é pressuposta por não ter sido posta por nenhuma autoridade competente, cuja competência teria que ser conferida por norma hierarquicamente superior. É, ainda, norma pressuposta na medida em que se interpreta o sentido subjetivo dos fatos geradores das normas em conformidade com a Constituição como sendo o seu sentido objetivo:

Dado que o fundamento de validade de uma norma somente pode ser outra norma, este pressuposto tem de ser uma norma: não uma norma posta por uma autoridade jurídica, mas uma norma pressuposta, quer dizer, uma norma que é pressuposta sempre que o sentido subjetivo dos fatos geradores de normas postas de conformidade com a Constituição é interpretado como o seu sentido objetivo [...]. Na medida em que só através da pressuposição da norma fundamental se torna possível interpretar o sentido subjetivo do fato constituinte e dos fatos postos de acordo com a Constituição como seu sentido objetivo, quer dizer, como normas objetivamente válidas, pode a norma fundamental [...] ser designada como a condição lógico-transcendental desta interpretação ${ }^{37}$.

Isto posto, é certo dizer que Kelsen contribui com a ciência jurídica à medida que fornece a ela uma representação de todo o sistema ou de todo o universo do Direito, a famosa pirâmide hierárquica de normas. Todavia, também é certo dizer que a pressuposição da norma

35 KELSEN, Hans. Teoria pura do direito. 6. ed. São Paulo: Martins Fontes, 1998. p. 51.

${ }^{36}$ KELSEN, Hans. Teoria pura do direito. 6. ed. São Paulo: Martins Fontes, 1998. p. 217.

${ }^{37}$ KELSEN, Hans. Teoria pura do direito. 6. ed. São Paulo: Martins Fontes, 1998. p. 224. 
fundamental, tida, por um lado, como imprescindível ao estudo científico da validade das normas jurídicas e, por outro, como mera ficção, representa um limite da Teoria Pura. Aliás, o próprio autor vem a admitir, posteriormente, que essa norma pressuposta é uma ficção, ou seja, que é como se ela existisse, mas não que ela realmente exista:

A norma fundamental de uma ordem jurídica ou moral positivas [...] não é positiva, mas meramente pensada, e isto significa uma norma fictícia, não o sentido real de ato de vontade, mas sim de um ato meramente pensado. Como tal, ela é uma pura ou 'verdadeira' ficção no sentido da vaihingeriana Filosofia do Como-se, que é caracterizada pelo fato de que ela não somente contradiz a realidade, como também é contraditória em si mesma. [...] Segundo Vaihinger, uma ficção é um recurso do pensamento do qual se serve se não pode alcançar o fim do pensamento com o material existente ${ }^{38}$.

Também merece destaque o fato de que a norma fundamental vem a admitir todo e qualquer direito positivo como válido, já que engendra a interpretação do sentido subjetivo dos fatos geradores da primeira Constituição como sendo seu sentido objetivo, o que daria margem a uma concepção de legalidade absolutamente independente de quaisquer limites éticos ou morais. Qualquer Constituição minimamente eficaz seria válida e, por encontrar respaldo na pressuposição de uma norma fundamental, deveria ser seguida ${ }^{39}$. Quer dizer, não poderíamos negar o status de validade jurídica a uma norma em razão de seu conteúdo ${ }^{40}$. Isso remete ao próprio princípio metodológico fundamental, que exige uma ciência formalmente rigorosa e universal.

Por esses motivos, a ideia de Kelsen a respeito de uma norma pressuposta é, então, idealista e formal ${ }^{41}$, se bem que exatamente atenta ao que sempre foi pelo autor projetado: a purificação da ciência jurídica. Não poderia Kelsen fundamentar todo o arcabouço jurídico a partir de um poder político ou de valores morais, como justiça ou dignidade da pessoa humana. Tudo diria respeito ao conteúdo da norma jurídica, altamente variável, e, por isso mesmo, incapaz de ser fundamento do próprio Direito.

Muito embora o pensamento político de Kelsen tenha profundas matrizes liberais e democratas $^{42}$, o autor sempre foi acusado de dar respaldo ora ao fascismo, ora ao liberalismo,

\footnotetext{
${ }^{38}$ KELSEN, Hans. Teoria geral das normas. Porto Alegre: Sergio Fabris, 1986. p. 328.

${ }^{39}$ KELSEN, Hans. O que é a justiça? São Paulo: Martins Fontes, 2001. p. 251.

40 KELSEN, Hans. Teoria pura do direito. 6. ed. São Paulo: Martins Fontes, 1998. p. 221.

${ }^{41}$ FERRAZ JR, Tercio Sampaio. Introdução ao estudo do direito: técnica, decisão, dominação. 8. ed. São Paulo: Atlas, 2015. p. 146.

${ }^{42}$ SGARBI, Adrian. O mundo de Kelsen. São Paulo: Marcial Pons, 2019. p. 127.
} 
ora ao socialismo ${ }^{43}$, eis que formulou uma teoria de uma “[...] ciência jurídica livre" ${ }^{44}$, capaz de admitir como válido qualquer direito, contanto que fossem observados aspectos formais de competência e hierarquia de normas, o que, em última instância, encontra razão na norma fundamental. Ainda assim, tais acusações podem soar bastante descabidas, dado que o autor, de origem judaica, foi obrigado a fugir, em razão do antissemitismo nazista, para os Estados Unidos, lecionando na Universidade de Berkeley a partir de 1942.

Ademais, seu pensamento político também sempre criticou o socialismo, porque igualmente antidemocrático ou autocrático. A questão, para Kelsen, é que a democracia é o único regime em que os cidadãos participam da criação ordem jurídica à qual se submetem ${ }^{45}$; em que há, necessariamente, conflito de ideias e tolerância como algo positivo ${ }^{46}$; proteção às minorias ${ }^{47}$; e o único em que pode haver liberdade científica, fator caro à justiça, na opinião pessoal do autor ${ }^{48}$.

Finalmente, em que pese ter dedicadas pouquíssimas páginas a respeito do tema, o problema da interpretação jurídica, ou da hermenêutica jurídica, também não passou despercebido a Kelsen ${ }^{49}$. Para ele, a interpretação do Direito consiste na fixação do sentido da norma jurídica ${ }^{50}$.

Por mais que a norma jurídica superior estabeleça forma e conteúdo a serem seguidos pela norma inferior, aquela não o pode fazer em todas as direções. Tem sempre de ficar uma margem, intencional ou não, maior ou menor, de livre apreciação, de tal sorte que a norma superior tem sempre, em relação ao ato de produção normativa ou de execução que a aplica, o caráter de um quadro ou moldura a preencher por esse ato $^{51}$. É devido a essa relativa

\footnotetext{
${ }^{43}$ KELSEN, Hans. Teoria pura do direito. 6. ed. São Paulo: Martins Fontes, 1998. p. XIII.

${ }^{44}$ KELSEN, Hans. Teoria pura do direito. 6. ed. São Paulo: Martins Fontes, 1998. p. XV.

${ }^{45}$ KELSEN, Hans. Teoria pura do direito. 6. ed. São Paulo: Martins Fontes, 1998. p. 155.

SGARBI, Adrian. 0 mundo de Kelsen. São Paulo: Marcial Pons, 2019. p. 128.

${ }^{46}$ KELSEN, Hans. 0 que é a justiça? São Paulo: Martins Fontes, 2001. p. 24.

47 SGARBI, Adrian. O mundo de Kelsen. São Paulo: Marcial Pons, 2019. p. 133.

${ }^{48}$ KELSEN, Hans. 0 que é a justiça? São Paulo: Martins Fontes, 2001. p. 25.

49 COELHO, Fábio Ulhoa. Para entender Kelsen. São Paulo: Saraiva, 2012. p. 78

FERRAZ JR, Tercio Sampaio. Introdução ao estudo do direito: técnica, decisão, dominação. 8. ed. São Paulo: Atlas, 2015. p. 217.

KELSEN, Hans. Teoria pura do direito. 6. ed. São Paulo: Martins Fontes, 1998. p. 387.

SGARBI, Adrian. O mundo de Kelsen. São Paulo: Marcial Pons, 2019. p. 76.

${ }^{50}$ KELSEN, Hans. Teoria pura do direito. 6. ed. São Paulo: Martins Fontes, 1998. p. 390.

${ }^{51}$ KELSEN, Hans. Teoria pura do direito. 6. ed. São Paulo: Martins Fontes, 1998. p. 390.
} 
indeterminação de sentido, ou, no dizer de Tercio Sampaio Ferraz Jr., diante desses conteúdos normativos vagos e ambíguo ${ }^{52}$, que Kelsen formulará a sua teoria da moldura:

O Direito a aplicar forma, em todas estas hipóteses, uma moldura dentro da qual existem várias possibilidades de aplicação, pelo que é conforme ao Direito todo ato que se mantenha dentro deste quadro ou moldura, que preencha esta moldura em qualquer sentido possível. Se por "interpretação" se entende a fixação por via cognoscitiva do sentido do objeto a interpretar, o resultado de uma interpretação jurídica somente pode ser a fixação da moldura que representa o Direito a interpretar e, consequentemente, o conhecimento das várias possibilidades que dentro desta moldura existem. Sendo assim, a interpretação de uma lei não deve necessariamente conduzir a uma única solução como sendo a única correta, mas possivelmente a várias soluções que apenas sejam aferidas pela lei a aplicar - têm igual valor, se bem que apenas uma delas se torne Direito positivo no ato do órgão aplicador do Direito - no ato do tribunal, especialmente. Dizer que uma sentença judicial é fundada na lei, não significa, na verdade, senão que ela se contém dentro da moldura ou quadro que a lei representa - não significa que ela é a norma individual, mas apenas que é uma das normas individuais que podem ser produzidas dentro da moldura da norma geral ${ }^{53}$.

Aliás, cabe dizer que o próprio termo "Direito" é dotado de ambiguidade e vagueza, sendo definido a partir dos usos da língua ${ }^{54}$. Mas, voltando ao específico cenário da imprecisão semântica das normas jurídicas, Kelsen assevera que o papel do jurista científico é apenas o de conhecer e de descrever essas diversas possibilidades de sentido da norma jurídica, deixando ao órgão aplicador do Direito o papel de escolher e decidir dentre elas:

Desta forma, existem duas espécies de interpretação que devem ser distinguidas claramente uma da outra: a interpretação do Direito pelo órgão que o aplica, e a interpretação do Direito que não é realizada por um órgão jurídico mas por uma pessoa privada e, especialmente, pela ciência jurídica ${ }^{55}$.

Por tal motivo, existem duas espécies de interpretação: a autêntica e a doutrinária ${ }^{56}$. A primeira é feita por órgãos competentes baseando-se em um ato cognoscitivo (de conhecimento) combinado com um ato volitivo (de vontade, de escolha), sendo que o resultado dessa

52 FERRAZ JR, Tercio Sampaio. Introdução ao estudo do direito: técnica, decisão, dominação. 8. ed. São Paulo: Atlas, 2015. p. 218.

53 KELSEN, Hans. Teoria pura do direito. 6. ed. São Paulo: Martins Fontes, 1998. p. 391, grifos do autor.

${ }^{54}$ FERRAZ JR, Tercio Sampaio. Introdução ao estudo do direito: técnica, decisão, dominação. 8. ed. São Paulo: Atlas, 2015. p. 16.

KELSEN, Hans. O que é a justiça? São Paulo: Martins Fontes, 2001. p. 286.

${ }^{55}$ KELSEN, Hans. Teoria pura do direito. 6. ed. São Paulo: Martins Fontes, 1998. p. 288.

${ }^{56}$ KELSEN, Hans. Teoria pura do direito. 6. ed. São Paulo: Martins Fontes, 1998. p. 395. 
interpretação é vinculante e criador de direito. Já a outra, não-autêntica ou doutrinária, é aquela feita por todos que não o órgão competente, e feita, em especial, pelos cientistas do Direito, em nome do conhecimento.

Já que o aplicador do Direito, o juiz ou o tribunal, intérprete autêntico, tem a necessidade de decidir acerca dos sentidos possíveis da norma jurídica para poder aplicá-la, ele tem, portanto, um poder de escolha, típico de um ato de vontade. De outra feita, o cientista do Direito, intérprete doutrinário, o jurista científico, porquanto fiel ao seu compromisso com o conhecimento purificado, não poderia se deixar levar por poder de escolha ou ato de vontade. Não poderia, jamais, o cientista dizer qual deveria ser a interpretação mais justa, pois isso seria feito por intermédio de um juízo de valor que contaminaria a ciência jurídica.

Não há nada, do ponto de vista científico, que priorize que determinado sentido seja o fixado em detrimento de outro, todos têm igual valor ${ }^{57}$. Quando um órgão judicial fixa certo sentido, o faz em razão de um ato volitivo, e não de um ato meramente cognoscitivo. É um ato de política jurídica, e não de ciência jurídica. A interpretação do jurista científico deveria ser limitada a desenvolver um método capaz de preencher a moldura deixada pela relativa indeterminação de sentido da norma ${ }^{58}$. Por essa razão, Kelsen distingue o intérprete autêntico e do doutrinário:

Daí as conclusões kelsenianas de todos conhecidas: a interpretação dos órgãos jurídicos (os tribunais, por exemplo) é um problema de vontade (interpretação como ato de vontade), no qual o intérprete sempre possui um espaço que poderá preencher no momento da aplicação da norma (é a chamada "moldura da norma", que, no limite, pode até ser ultrapassada). Já a interpretação que o cientista do direito realiza é um ato de conhecimento que pergunta logicamente - pela validade dos enunciados jurídicos ${ }^{59}$.

Destarte, Kelsen se mantém fiel ao princípio metodológico fundamental, mas deixa o jurista científico, novamente, em uma camisa de força. Não pode ele, como já assinalado alhures, engajar-se com nenhuma crítica ao Direito. Nem mesmo pode recomendar ao órgão aplicador do juiz ou tribunal que determinado sentido seja fixado para certa norma ${ }^{60}$. Há, assim, mais uma vez, o fato de que o autor traz contribuições e limites à ciência jurídica:

\footnotetext{
${ }^{57}$ COELHO, Fábio Ulhoa. Para entender Kelsen. São Paulo: Saraiva, 2012. p. 81.

58 KELSEN, Hans. Teoria pura do direito. 6. ed. São Paulo: Martins Fontes, 1998. p. 391.

59 STRECK, Lenio Luiz. 0 que é isto - decido conforme minha consciência? 5. ed. Porto Alegre: Livraria do Advogado, 2015. p. 81, grifos do autor.

60 KELSEN, Hans. 0 que é a justiça? São Paulo: Martins Fontes, 2001. p. 367.
} 
Penso, contudo, que a contribuição de Kelsen é paradoxal. Se, de um lado, inegavelmente, ele levou o projeto de construção da ciência do direito às últimas consequências - e o fez com absoluto rigor, método, logicidade e destreza -, de outro, criou as condições teóricas para a superação do mesmo projeto. Ao pretender expandir até os seus limites a afirmação da possibilidade do conhecimento científico do direito, Kelsen acabou revelando tais limites e pondo a nu as insuficiências dessa propositura epistemológica ${ }^{61}$.

Então, no que tange à hermenêutica jurídica, por um lado, há a grande contribuição de desmistificar a ideia de interpretação única e verdadeira, de um sentido pronto e pré-acabado da norma jurídica, o qual deve ser descoberto por um intérprete do modo mais passivo possível em nome da mais alta justiça. Isso seria uma proposta política escondida debaixo do manto da cientificidade $^{62}$, se bem que em busca de uma utópica segurança jurídica:

A doutrina de que uma norma jurídica tem efetivamente apenas um significado e de que existe um método científico que nos capacita sempre a descobrir o seu único significado correto é uma ficção usada pela ciência jurídica tradicional para sustentar a ilusão da segurança jurídica ${ }^{63}$.

Há, também, outra contribuição que merece ser apontada, aquela consistente na relação que Kelsen admite entre interpretação e poder. Todavia, o autor limita essa relação ao âmbito do intérprete autêntico, aquele que, por ato volitivo, resolve sobre qual é o sentido a ser fixado para determinada norma jurídica e, assim, formula resultado vinculante e criador de direito.

Ainda, cumpre salientar que, na seara da interpretação autêntica, há a possibilidade de se decidir, inclusive, para além dos limites da moldura, mesmo que isso seja rejeitado do ponto de vista da ciência do direito; pois é o intérprete autêntico que, ao final, decide qual o sentido que será fixado para determinada norma ${ }^{64}$. Daí a ligação entre interpretação e poder, espelhada na ideia de que é sim possível uma decisão judicial completamente ímpar diante da moldura apontada pela ciência jurídica:

A propósito importa notar que, pela via da interpretação autêntica, quer dizer, da interpretação de uma norma pelo órgão jurídico que a tem de aplicar, não

\footnotetext{
${ }^{61}$ COELHO, Fábio Ulhoa. Para entender Kelsen. São Paulo: Saraiva, 2012. p. 92.

62 FERRAZ JR, Tercio Sampaio. Introdução ao estudo do direito: técnica, decisão, dominação. 8. ed. São Paulo: Atlas, 2015. p. 219.

KELSEN, Hans. O que é a justiça? São Paulo: Martins Fontes, 2001. p. 367.

${ }^{63}$ KELSEN, Hans. O que é a justiça? São Paulo: Martins Fontes, 2001. p. 366.

${ }^{64}$ KELSEN, Hans. Teoria pura do direito. 6. ed. São Paulo: Martins Fontes, 1998. p. 393.
} 
somente se realiza uma das possibilidades reveladas pela interpretação cognoscitiva da mesma norma, como também se pode produzir uma norma que se situe completamente fora da moldura que a norma a aplicar representa. Através de uma interpretação deste tipo pode criar-se Direito $[\ldots]^{65}$.

Por outro lado, em se tratando de limites à ciência jurídica, há um grande desafio, que é o de fundamentar a hermenêutica jurídica, o de fundamentar a interpretação feita pelo cientista jurídico, ao invés de deixá-lo refém ao arbítrio, ao bel-prazer do intérprete autêntico. Ainda sobre isso, cabe dizer:

[...] numa analogia a um texto final de uma obra de Wittgenstein, lógico com quem Kelsen privou em seus tempos de Viena, segundo o qual 'o que não se pode falar, deve-se calar', poderíamos dizer que para nosso jurista, o que a ciência jurídica não pode descrever, deve omitir. Essa coerência de Kelsen com seus princípios metódicos, porém, deixa-nos sem armas. Sua renúncia pode ter um sentido heróico, de fidelidade à ciência, mas deixa sem fundamento a maior parte das atividades dogmáticas, as quais dizem respeito à hermenêutica. $E$ ademais não explica a diferença entre a mera opinião, não técnica, sobre o conteúdo da lei, exarada por alguém que sequer tenha estudado Direito e a opinião do doutrinador, que busca, com os meios da razão jurídica, o sentido da norma. A diferença, em termos de aceitação, resta meramente política. Ou seja, para Kelsen, é possível denunciar, de um ângulo filosófico (zetético), os limites da hermenêutica, mas não é possível fundar uma teoria dogmática da interpretação [...] Não teria, pois, realmente nenhum valor racional procurar um fundamento teórico para a atividade metódica de doutrina, quando esta busca e atinge o sentido unívoco das palavras da lei? Seria um contrassenso falar em verdade hermenêutica? Enfrentar essa questão constitui o que chamaríamos, então, de o desafio kelseniano ${ }^{66}$.

A partir dessa postura hermenêutica, cabe agora analisar o julgamento, pelo Supremo Tribunal Federal, acerca da criminalização da homofobia e da transfobia, tudo a fim de se verificar se há elementos da hermenêutica jurídica kelseniana que ajudem na compreensão de tal decisão.

${ }^{65}$ KELSEN, Hans. Teoria pura do direito. 6. ed. São Paulo: Martins Fontes, 1998. p. 394.

${ }^{66}$ FERRAZ JR, Tercio Sampaio. Introdução ao estudo do direito: técnica, decisão, dominação. 8. ed. São Paulo: Atlas, 2015. p. 219, grifos do autor. 


\section{O JULGAMENTO DA CRIMINALIZAÇÃO DA HOMOFOBIA E DA TRANSFOBIA NO SUPREMO TRIBUNAL FEDERAL}

Conforme assinalado alhures, os temas da homofobia e da transfobia no Brasil são vastíssimos e não se quer, com este artigo, nem remotamente esgotá-los. Apenas na jurisprudência do Supremo Tribunal Federal, os referidos temas perpassam pela Arguição de Descumprimento Fundamental (ADPF) $132^{67}$ e pela Ação Direta de Inconstitucionalidade (ADI) $4277^{68}$ - ambas sobre a união homoafetiva -, pela Ação Direta de Inconstitucionalidade (ADI) $4275^{69}$ - sobre a transexualidade a o nome civil -, e, agora, pela Ação Direta de Inconstitucionalidade por Omissão (ADO) $26^{70}$ e pelo Mandado de Injunção (MI) $4733^{71}$ - sobre a criminalização da homofobia e da transfobia. Por isso, trata-se, aqui, especificamente, destas duas últimas ações, julgadas conjuntamente.

Em apertada síntese, nelas se discutiu a mora e omissão do Congresso Nacional em legislar no sentido de criminalizar as práticas de homofobia e de transfobia, o papel do Supremo Tribunal Federal frente à separação de poderes, a equiparação temporária dessas práticas às de racismo feita pelo judiciário em contraponto aos princípios de direito penal. 0 julgamento foi encerrado por oito votos a três. Ficou decidido que o legislativo se mantém omisso e deve, em

\footnotetext{
${ }^{67}$ BRASIL. Supremo Tribunal Federal. Acórdão da decisão que reconheceu a união homoafetiva. Arguição de Descumprimento de Preceito Fundamental 132. Governador do Estado do Rio de Janeiro. Relator: Ministro Ayres Britto. 05 de maio de 2011. Disponível em: http://redir.stf.jus.br/paginadorpub/paginador.jsp?docTP=AC\&doclD=628633. Acesso em 12 de jul. de 2019.

${ }^{68}$ BRASIL. Supremo Tribunal Federal. Acórdão da decisão que reconheceu a união homoafetiva Ação Direta de Inconstitucionalidade 4.277. Procuradoria Geral da República. Relator: Ministro Ayres Britto. 05 de maio de 2011. Disponível http://redir.stf.jus.br/paginadorpub/paginador.jsp?docTP=AC\&docID=628635. Acesso em 12 de jul. de 2019.

69 BRASIL. Supremo Tribunal Federal. Acórdão da decisão que permitiu a retificação do nome civil independentemente de cirurgia de transgenitalização. Ação Direta de Inconstitucionalidade. 4.275. Procuradoria Geral da República. Relator para o acórdão: Ministro Edson Fachin. 07 de março de 2019. Disponível em: http://stf.jus.br/portal/jurisprudencia/listarJurisprudencia.asp?s1=\%28ADI\%24\%2ESCLA\%2E+E+4275\%2ENU ME\%2E\%29+OU+\%28ADI\%2EACMS\%2E+ADJ2+4275\%2EACMS\%2E\%29\&base=baseAcordaos\&url=http: / / tinyurl.co m/aju5rhv. Acesso em 12 de jul. de 2019.

${ }_{70}$ BRASIL. Supremo Tribunal Federal. Ação Direta de Inconstitucionalidade por Omissão $\mathrm{n}^{\circ}$ 26. Partido Popular Socialista. Relator: Ministro Celso de Mello. Disponível em: http://portal.stf.jus.br/processos/detalhe.asp?incidente=4515053. Acesso em: 12 jul. 2019.

71 BRASIL. Supremo Tribunal Federal. Mandado de Injunção 4733. Associação Brasileira de Gays, Lésbicas e Transgêneros - ABGLT. Relator: Ministro Edson Fachin. Disponível em: https://portal.stf.jus.br/processos/detalhe.asp?incidente=4239576. Acesso em 13 de jul. de 2019.
} 
prazo razoável, criminalizar a homofobia e a transfobia. Enquanto não haja legislação específica, ficou determinada a equiparação, de modo temporário, dessas condutas às práticas de racismo.

Focalizando no voto do relator, o Ministro Celso de Mello $^{72}$, é de se notar uma primeira e brevíssima constatação no sentido de que ele prevê que será criticado por setores conservadores da sociedade, incapazes de reconhecer o pluralismo e a tolerância como bases da democracia. Logo após, o Ministro passa a esboçar a controvérsia constitucional envolvida.

De acordo com os autores das ações, os membros do Congresso Nacional agem com manifesta indiferença à comunidade de Lésbicas, Gays, Bissexuais, Travestis, Transexuais, Queers, Intersexo e outros vulneráveis em razão da orientação sexual ou da identidade de gênero (LGBTQI+) ao se manterem silentes quando deveriam criminalizar práticas a ela atentatórias; e mais, eles, ao fazerem isso, descumprem o dever de proteção do Estado frente aos vulneráveis. Ainda de acordo com os autores da demanda, o fundamento da necessária equiparação da homofobia e da transfobia ao racismo reside no Caso Ellwanger, o HC $82.424 / \mathrm{RS}^{73}$. Do mesmo modo, também é fundamento o mandamento constitucional que impõe punição por qualquer discriminação atentatória aos direitos e liberdades fundamentais ${ }^{74}$.

Diante disso, em mais de trinta anos de Constituição, mostra-se absolutamente descabida e preconceituosa a atitude dos congressistas, o que ensejaria, inclusive, responsabilidade civil da União Federal. Desse modo, buscam os autores o reconhecimento formal da omissão do Congresso Nacional quanto à criminalização da homofobia e da transfobia, notificando-o quanto a isso e exigindo que ele, em prazo razoável, deixe de se manter inerte. Subsidiariamente, requerem que o próprio Supremo Tribunal Federal criminalize essas condutas, dada a excepcionalidade do caso. Por fim, pedem os autores a responsabilização civil da União pelos atos de preconceito em questão. Esses são os contornos da demanda.

72 BRASIL. Supremo Tribunal Federal. Voto do Relator, Ministro Celso de Mello. Ação Direta de Inconstitucionalidade por Omissão $\mathrm{n}^{\circ}$ 26. Partido Popular Socialista. Relator: Ministro Celso de Mello. 20 de fevereiro de 2019. Disponível em: https://www.conjur.com.br/dl/leia-voto-ministro-celso-mello2.pdf. Acesso em: 12 jul. 2019.

73 BRASIL. Supremo Tribunal Federal. Acórdão da denegação de Habeas Corpus para a concessão de liberdade ao paciente Siegfried Ellwanger, acusado pelo crime de racismo. Habeas Corpus 82.424/RS. Siegfried Ellwanger Castan. Relator para o acórdão: Ministro Maurício Corrêa. 17 de setembro de 2003. Disponível http://www.stf.jus.br/portal/geral/verPdfPaginado.asp?id=79052\&tipo=AC\&descricao=Inteiro\%20Teor\%20 HC\%20/\%2082424. Acesso em 12 de jul. de 2019.

74 BRASIL. Constituição Federal. Brasília: Senado Federal, 1988. Disponível em: http://www.planalto.gov.br/ccivil_03/constituicao/ConstituicaoCompilado.htm. Acesso em: 12 jul. 2019. 
Partindo, então, a explicar definições e questões terminológicas, o ministro relator assinala que a comunidade LGBTQI+, longe de constituir uma comunidade homogênea, é composta por membros cuja orientação sexual ou identidade de gênero o tornam vulneráveis. Outrossim, assinala a diferença entre sexo, gênero, identidade de gênero e orientação sexual ou sexualidade. Enquanto sexo conduz a uma perspectiva estritamente biológica, gênero é uma ideia assentada em fatores psicossociais e, por isso mesmo, ao comportamento e ao modo de ser de cada um em sociedade.

Por sua vez, identidade de gênero significa a possibilidade, absolutamente singular e profunda, de se identificar e de se vincular ou não aos parâmetros de gênero. Já a sexualidade envolve aspectos íntimos da personalidade, remetendo à questão da afetividade. Em que pese a centralidade de todas essas questões, certo é que muitos procuram deslegitimar a causa LGBTQI+, alegando que isso é “ideologia de gênero" ou "anti-natural”. Todavia, explica o ministro, é preciso reconhecer que gênero é algo artificialmente construído e que todos têm direito à autodeterminação do próprio gênero e à definição da própria orientação sexual.

Em um próximo tópico, o relator explica a inviabilidade de se apreciar casos individuais de violação em seio de controle concentrado ou abstrato de constitucionalidade, eis que este se reveste de objetividade. Por isso não há que se falar em responsabilidade civil da União no presente caso.

Em seguida, o ministro decide que não é possível que o Supremo Tribunal Federal proceda, ele próprio, diante da omissão legislativa, à tipificação penal. Para ele, o princípio da legalidade, que diz que não há crime sem lei anterior que o defina, afasta a possibilidade de definição de um crime a partir de entendimento jurisprudencial. Não há como se furtar à reserva absoluta da lei penal. Agora, é forçoso que se esboce um pouco mais sobre tal princípio.

De acordo com Zaffaroni e Batista ${ }^{75}$, o princípio da legalidade exige que apenas a lei em sentido estrito é que pode criminalizar condutas e cominar penas. É uma reserva absoluta de lei. Não se admite que a criminalização de condutas ou a cominação de penas sejam veiculadas por decisão judicial ou ato administrativo.

Enquanto desdobramento do princípio da legalidade geral, prevista no artigo $5^{\circ}$, inciso II da Constituição Federal $^{76}$, que diz que ninguém será obrigado a fazer ou deixar de fazer algo

75 ZAFFARONI, Eugenio Raúl; BATISTA, Nilo. Direito penal brasileiro: teoria geral do direito penal. Rio de Janeiro: Revan, 2003, v. 1. p. 200.

76 BRASIL. Constituição Federal. Brasília: Senado Federal, $1988 . \quad$ Disponível em: http://www.planalto.gov.br/ccivil_03/constituicao/ConstituicaoCompilado.htm. Acesso em: 12 jul. 2019. 
senão em virtude de lei, a legalidade penal diz, especificamente, que não há crime sem lei anterior que o defina, nem pena sem prévia cominação legal, o que está previsto no artigo $5^{\circ}$, inciso XXXIV da Constituição ${ }^{77}$ e no artigo $1^{\circ}$ do Código Penal $^{78}$. Esse princípio apresenta alguns desdobramentos, sendo, dentre eles, a taxatividade da lei e a proibição de analogia in malam partem.

Basicamente, quer isso dizer que as palavras da lei penal devem ter um significado minimamente preciso e que não é permitido ao juiz criminal "completar" as hipóteses legais. Existe um limite semântico imprescindível ao qual se deve se atentar, isto é, deve se fazer uma interpretação restritiva da lei penal.

Avançando, faz o relator considerações acerca dos registros históricos e das práticas sociais contemporâneas contrários aos direitos LGBTQI+. Para tal, o ministro retorna às ordenações portuguesas e pontua a atuação da inquisição no Brasil, tudo para mostrar as raízes do preconceito envolvendo orientação sexual e identidade de gênero no país. Isso leva o ministro a assinalar, em termos arenditianos, a banalidade do mal homofóbico e transfóbico, comprovado por meio de inúmeras notícias, estatísticas e relatórios sobre a violência envolvendo orientação sexual e identidade de gênero.

Diante desse cenário, de acordo com o julgador, há omissão legislativa, configurada na medida em que, por expressa disposição constitucional, a lei deveria punir qualquer discriminação a direitos e liberdades fundamentais ${ }^{79}$, inclusive aquelas fundadas em preconceito com relação à orientação sexual ou identidade de gênero. Neste sentido, os singelos projetos de lei no Congresso Nacional não são suficientes para sanar a omissão. Daí a mora inconstitucional.

Isto posto, o relator decide acerca das soluções possíveis para o caso. Reconhecida a omissão, o primeiro ponto é notificar o Congresso para que legisle, em prazo razoável, sobre a matéria em questão. Porém, enquanto não há legislação específica, decidiu o ministro pelo enquadramento imediato das práticas de homofobia e de transfobia no conceito de racismo, nos

77 BRASIL. Constituição Federal. Brasília: Senado Federal, 1988. Disponível em: http://www.planalto.gov.br/ccivil_03/constituicao/ConstituicaoCompilado.htm. Acesso em: 12 jul. 2019. ${ }_{78}$ BRASIL. Decreto Lei $n^{\circ}$ 2.848/40, de 1940. Código Penal. In: Diário Oficial da República Federativa do Brasil, Rio de Janeiro, RJ, 07 dez. 1940. Disponível em: http://www.planalto.gov.br/ccivil_03/decretolei/del2848compilado.htm Acesso em: 12 jul. 2019.

79 BRASIL. Constituição Federal. Brasília: Senado Federal, $1988 . \quad$ Disponível em: http://www.planalto.gov.br/ccivil_03/constituicao/ConstituicaoCompilado.htm. Acesso em: 12 jul. 2019. 
termos da Lei $7.716 / 89^{80}$. Aqui, parte-se de uma noção ampliada de racismo, seguindo a ideia do HC 82.424/RS ${ }^{81}$.

Aquele caso tratava de Siegfried Ellwanger, fundador de uma editora que veiculava publicações de cunho antissemita. A discussão girava em torno do fato de ser possível ou não considerar a religião judaica como raça, e, por isso, ser ou não possível o enquadramento da conduta de Ellwanger na Lei de Racismo. Então, naquele caso ficou decidido que raça não é um conceito propriamente biológico ou antropológico, mas social, cultural e político, vez que orienta uma conduta que tem como objetivo a discriminação e o apequenamento de determinado ser humano em razão de algum fator como cor da pele, etnia, nacionalidade e, inclusive, religião. Eis um trecho da ementa daquele julgado:

EMENTA: HABEAS-CORPUS. PUBLICACÃO DE LIVROS: ANTI-SEMITISMO. RACISMO. CRIME IMPRESCRITÍVEL. CONCEITUAÇÃO. ABRANGÊNCIA CONSTITUCIONAL. LIBERDADE DE EXPRESSÃO. LIMITES. ORDEM DENEGADA. [...] 3. Raça humana. Subdivisão. Inexistência. Com a definição e o mapeamento do genoma humano, cientificamente não existem distinções entre os homens, seja pela segmentação da pele, formato dos olhos, altura, pêlos ou por quaisquer outras características físicas, visto que todos se qualificam como espécie humana. Não há diferenças biológicas entre os seres humanos. Na essência são todos iguais. 4. Raça e racismo. A divisão dos seres humanos em raças resulta de um processo de conteúdo meramente político-social. Desse pressuposto origina-se o racismo que, por sua vez, gera a discriminação e o preconceito segregacionista. 5. Fundamento do núcleo do pensamento do nacional-socialismo de que os judeus e os arianos formam raças distintas. Os primeiros seriam raça inferior, nefasta e infecta, características suficientes para justificar a segregação e o extermínio: inconciliabilidade com os padrões éticos e morais definidos na Carta Política do Brasil e do mundo contemporâneo, sob os quais se ergue e se harmoniza o estado democrático. Estigmas que por si só evidenciam crime de racismo. Concepção atentatória dos princípios nos quais se erige e se organiza a sociedade humana, baseada na respeitabilidade e dignidade do ser humano e de sua pacífica convivência no meio social. Condutas e evocações aéticas e imorais que implicam repulsiva ação estatal por se revestirem de densa intolerabilidade, de sorte a afrontar o ordenamento infraconstitucional e constitucional do País. 6. Adesão do Brasil a tratados e acordos multilaterais, que energicamente repudiam quaisquer discriminações raciais, aí compreendidas as distinções entre os homens por restrições ou preferências oriundas de raça, cor, credo, descendência ou origem

${ }^{80}$ BRASIL. Lei $n^{\circ} 7.716 / 89$, de 1989. Define crimes resultantes de preconceito de raça ou de cor. In: Diário Oficial da República Federativa do Brasil, Brasília, DF, 05 jan. 1989. Disponível em: http://www.planalto.gov.br/ccivil_03/leis/l7716.htm. Acesso em: 12 jul. 2019.

81 BRASIL. Supremo Tribunal Federal. Acórdão da denegação de Habeas Corpus para a concessão de liberdade ao paciente Siegfried Ellwanger, acusado pelo crime de racismo. Habeas Corpus 82.424/RS. Siegfried Ellwanger Castan. Relator para o acórdão: Ministro Maurício Corrêa. 17 de setembro de 2003. Disponível

em: http: //www.stf.jus.br/portal/geral/verPdfPaginado.asp?id=79052\&tipo=AC\&descricao=Inteiro\%20Teor\%20 $\underline{\mathrm{HC} \% 20 / \% 2082424}$. Acesso em 12 de jul. de 2019. 
nacional ou étnica, inspiradas na pretensa superioridade de um povo sobre outro, de que são exemplos a xenofobia, 'negrofobia', 'islamafobia' e o anti-semitismo. 7. A Constituição Federal de 1988 impôs aos agentes de delitos dessa natureza, pela gravidade e repulsividade da ofensa, a cláusula de imprescritibilidade, para que fique, 'ad perpetuam rei memoriam', verberado o repúdio e a abjeção da sociedade nacional à sua prática. 8. Racismo. Abrangência. Compatibilização dos conceitos etimológicos, etnológicos, sociológicos, antropológicos ou biológicos, de modo a construir a definição jurídico-constitucional do termo. Interpretação teleológica e sistêmica da Constituição Federal, conjugando fatores e circunstâncias históricas, políticas e sociais que regeram sua formação e aplicação, a fim de obter-se o real sentido e alcance da norma $[\ldots]^{82}$.

Agora, o ministro diz que é necessário que se enquadre como raça a prática de homofobia e de transfobia, porque igualmente voltadas à discriminação e apequenamento de alguém de acordo com sua orientação sexual ou identidade de gênero. Ainda de acordo com o julgador, é exatamente por esses dois fatores estarem contidos na ideia de raça é que não há analogia in malam partem. Homofobia e transfobia não são conceitos distantes do conceito de raça, mas a ele parecidos e, por serem tão parecidos, atraem a aplicação da Lei de Racismo ${ }^{83}$.

Desse modo, o judiciário, em sua atividade hermenêutica, há de tornar efetiva a reação estatal na prevenção e repressão dos atos de preconceito e contra pessoas vulneráveis, aos olhos do ministro, notadamente quando dirigidos a membro da comunidade LGBTQI+.

Outro ponto que mereceu atenção é a discussão entre repressão à homotransfobia e liberdade religiosa. Para o ministro relator, não há qualquer inconstitucionalidade nisso, pois, apesar de essencial a qualquer regime democrático e de ser vedada a censura prévia, a liberdade de expressão não é absoluta.

Mensagens de líderes religiosos pautadas em seus livros sagrados estão agasalhadas pela Constituição. Contudo, não é permitido que fora desses limites se veicule mensagens racistas, xenofóbicas ou homotransfóbicas sem risco de responsabilização ulterior. Prova disso são os delitos contra a honra. $O$ ódio público, nesse entender, não pode ser contemplado.

\footnotetext{
82 BRASIL. Supremo Tribunal Federal. Acórdão da denegação de Habeas Corpus para a concessão de liberdade ao paciente Siegfried Ellwanger, acusado pelo crime de racismo. Habeas Corpus 82.424/RS. Siegfried Ellwanger Castan. Relator para o acórdão: Ministro Maurício Corrêa. 17 de setembro de 2003. Disponível http://www.stf.jus.br/portal/geral/verPdfPaginado.asp?id=79052\&tipo=AC\&descricao=Inteiro\%20Teor\%20 HC\%20/\%2082424. Acesso em 12 de jul. de 2019.

${ }_{83}$ BRASIL. Lei $n^{\circ} 7.716 / 89$, de 1989. Define crimes resultantes de preconceito de raça ou de cor. In: Diário Oficial da República Federativa do Brasil, Brasília, DF, 05 jan. 1989. Disponível em: http://www.planalto.gov.br/ccivil_03/leis/l7716.htm. Acesso em: 12 jul. 2019.
} 
Terminando o seu voto, o relator diz que a democracia constitucional exige uma função contramajoritária do Supremo Tribunal Federal, pois democracia não se faz sem a proteção de minorias, inclusive da comunidade LGBTQI+. É necessário que se assegure a elas o direito de busca à felicidade como proteção do princípio fundamental da dignidade da pessoa humana.

Ao final, observa o ministro que cabe ao guardião da Constituição, justamente, a tarefa de zelar pelas normas constitucionais e de direitos humanos, razão pela qual não há que se falar, nos limites do caso da criminalização da homofobia e da transfobia, na interferência do judiciário em questões que seriam relegadas ao legislativo. Assim, finaliza o relator o seu voto ao dizer sobre a grandeza do julgamento e da atuação do Supremo Tribunal Federal:

Encerro o meu voto, Senhor Presidente, enfatizando que este processo revela que, nele, está em debate, uma vez mais, o permanente conflito entre civilização e barbárie, cabendo ao Supremo Tribunal Federal fazer prevalecer, em toda a sua grandeza moral, a essencial e inalienável dignidade das pessoas, em solene reconhecimento de que, acima da estupidez humana, acima da insensibilidade moral, acima das distorções ideológicas, acima das pulsões irracionais e acima da degradação torpe dos valores que estruturam a ordem democrática, deverão sempre preponderar os princípios que exaltam e reafirmam a superioridade ética dos direitos humanos, cuja integridade será preservada, aqui e agora, em prol de todos os cidadãos e em respeito à orientação sexual e à identidade de gênero de cada pessoa que vive sob a égide dos postulados que informam o próprio conceito de República ${ }^{84}$.

O relator foi acompanhado pela maior parte dos ministros. Os ministros Celso de Mello, Edson Fachin, Alexandre de Moraes, Luís Roberto Barroso, Rosa Weber, Luiz Fux, Cármen Lúcia e Gilmar Mendes também votaram pelo enquadramento temporário da homofobia e da transfobia como tipo penal definido na Lei de Preconceito até que o Congresso Nacional legisle sobre a matéria.

Contudo, houve divergência. Foram divergentes os ministros Ricardo Lewandovski, Dias Toffoli e Marco Aurélio Mello. Os dois primeiros reconheceram a mora inconstitucional por parte do legislativo, mas consignaram que não há que se falar em equiparação temporária, a mando do judiciário, das práticas de homofobia e de transfobia à de racismo, nos termos da Lei 7.716/8985.

84 BRASIL. Supremo Tribunal Federal. Voto do Relator, Ministro Celso de Mello. Ação Direta de Inconstitucionalidade por Omissão $\mathrm{n}^{\circ}$ 26. Partido Popular Socialista. Relator: Ministro Celso de Mello. 20 de fevereiro de 2019. Disponível em: https://www.conjur.com.br/dt/leia-voto-ministro-celso-mello2.pdf. Acesso em: 12 jul. 2019. p. 155.

${ }^{85}$ BRASIL. Lei $n^{\circ} 7.716 / 89$, de 1989. Define crimes resultantes de preconceito de raça ou de cor. In: Diário Oficial da República Federativa do Brasil, Brasília, DF, 05 jan. 1989. Disponível em: http://www.planalto.gov.br/ccivil_03/leis/l7716.htm. Acesso em: 12 jul. 2019. 
Sem negar a importância do tema, nem mesmo a omissão inconstitucional, decidiu, então, o ministro Lewandovski, que não cabe ao Supremo Tribunal Federal legislar a respeito da criminalização, dado que isso arranharia, fora a separação de poderes, o princípio da legalidade e da taxatividade da lei penal:

A extensão do tipo penal para abarcar situações não especificamente tipificadas pela norma penal incriminadora parece-me atentar contra o princípio da reserva legal, que constitui uma fundamental garantia dos cidadãos, que promove a segurança jurídica de todos. Ante o exposto, voto no sentido de que, parcialmente conhecida, seja parcialmente provida esta ação, de maneira a reconhecer a mora legislativa, dando-se ciência ao Congresso Nacional para a adoção das providências necessárias ${ }^{86}$.

No mais, o ministro Marco Aurélio apontou que não há mora do Congresso Nacional no sentido de não legislar criminalizando essas práticas contra a comunidade LGBTQI+. E não caberia ao judiciário determinar a criminalização, pois isso colidiria com os princípios da separação de poderes, legalidade e taxatividade da lei penal. Ainda assim, reconheceu que o tema de proteção a minorias seja importante e legítima pauta política.

De toda forma, ficou decidido, por maioria dos ministros do Supremo Tribunal Federal, que há flagrante mora inconstitucional por parte do Congresso Nacional em não legislar de modo a criminalizar a homofobia e a transfobia. Por isso, ele deve fazê-lo em tempo razoável. No entanto, enquanto não o fizer, há a equiparação temporária dessas práticas preconceituosas à noção de raça, abarcada pela Lei de Racismo ${ }^{87}$.

Então, é imperioso dizer que a discussão não recaiu propriamente sobre a legitimidade da bandeira arco-íris ou da bandeira trans. Aliás, nem se discutiu as relações que existem e aquelas que poderiam e deveriam existir, em um Estado Democrático de Direito, entre homotransfobia e direito penal ou criminologia, como já esboçava Salo de Carvalho ${ }^{88}$.

Em verdade, o que se discutiu nesse julgamento foi a omissão legislativa inconstitucional e o papel do Supremo frente a ela, destacando-se o poder de equiparação

\footnotetext{
86 BRASIL. Supremo Tribunal Federal. Voto do Ministro Ricardo Lewandoski. Ação Direta de Inconstitucionalidade por Omissão $\mathrm{n}^{\circ}$ 26. Partido Popular Socialista. Relator: Ministro Celso de Mello. 13 de junho de 2019. Disponível em: https://www.conjur.com.br/dl/legislativo-tipificar-crime-defende.pdf. Acesso em 12 jul. 2019. p. 19.

${ }^{87}$ BRASIL. Lei $n^{\circ} 7.716 / 89$, de 1989. Define crimes resultantes de preconceito de raça ou de cor. In: Diário Oficial da República Federativa do Brasil, Brasília, DF, 05 jan. 1989. Disponível em: http://www.planalto.gov.br/ccivil_03/leis/l7716.htm. Acesso em: 12 jul. 2019.

${ }_{88}$ CARVALHO, Salo de; DUARTE, Evandro Piza. Criminologia do Preconceito: racismo e homofobia nas Ciências Criminais. São Paulo: Saraiva, 2017.
} 
temporária da homotransfobia à prática de racismo. Em suma, discutiu-se o modo pelo qual a criminalização foi feita, e não o mérito da luta da comunidade LGBTQI+ em prol de seus direitos.

Após a análise do julgamento, passa-se ao ponto mais importante deste ensaio, que diz respeito exatamente à análise dele por meio da hermenêutica jurídica de Hans Kelsen. Assim, questiona-se: como se verifica a hermenêutica jurídica em Kelsen como ferramenta para a compreensão desse julgamento?

\section{O JULGAMENTO À LUZ DA HERMENÊUTICA JURÍDICA KELSENIANA}

Inicialmente, é preciso frisar que o campo de análise da ciência jurídica é, para Kelsen, bastante restrito. Se se atentar à especificidade do objeto de estudo e ao princípio metodológico fundamental, tal qual o autor o fez, cabe ao jurista científico apenas conhecer e descrever a norma jurídica e seus diversos significados possíveis. No caso da criminalização da homofobia e da transfobia, percebe-se, desde logo, que há uma relativa indeterminação de significados possíveis à noção de raça, nos termos da Lei de Racismo ${ }^{89}$.

Como à ciência jurídica, de um modo geral, cabe apenas conhecer e descrever essa plurissignificação, aos penalistas, em particular, cabe dizer que, em se tratando de direito penal, as palavras devem ter essa relativa indeterminação de sentido reduzida ao máximo. Caso contrário, violar-se-ia, fora a separação de poderes, o princípio da legalidade, tanto mais em uma faceta específica, que é o princípio da taxatividade ${ }^{90}$. Mas é de suma importância que o cientista da área penal se atenha apenas a essa descrição, em ordem de não violar seu princípio metodológico fundamental, ou seja, de não se contaminar por valores morais de justiça e prostituir a ciência à uma ideologia política, ao invés de se dedicar ao conhecimento da verdade.

Além disso, é importante destacar que o ordenamento jurídico se constitui como um conjunto escalonado de normas, de modo que a norma superior fornece o fundamento de validade à norma inferior até que se remeta à norma fundamental. É a conhecida pirâmide kelseniana. Nessa representação do sistema jurídico, a constituição representa o ápice da

\footnotetext{
${ }^{89}$ BRASIL. Lei $n^{\circ} 7.716 / 89$, de 1989. Define crimes resultantes de preconceito de raça ou de cor. In: Diário Oficial da República Federativa do Brasil, Brasília, DF, 05 jan. 1989. Disponível em: http://www.planalto.gov.br/ccivil_03/leis/l7716.htm. Acesso em: 12 jul. 2019.

${ }_{90}$ ZAFFARONI, Eugenio Raúl; BATISTA, Nilo. Direito penal brasileiro: teoria geral do direito penal. Rio de Janeiro: Revan, 2003, v. 1. p. 200.
} 


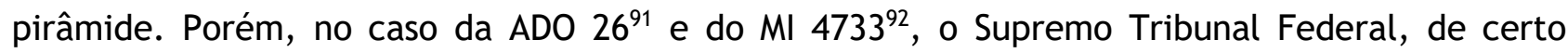
modo, procedeu com a inversão dessa pirâmide, na medida em que fez sua decisão prevalecer sobre os limites da Lei de Racismo ${ }^{93}$ e sobre a própria Constituição Federal ${ }^{94}$.

Sobre a lei, porque o conceito de raça não comportaria o significado de orientação sexual e identidade de gênero, de acordo com a ciência jurídica. Sobre a Constituição, porque a taxatividade, a redução da indeterminação dos significados possíveis está implícita na legalidade e mesmo assim isso não foi observado. 0 acórdão, assim, não se limita à base da pirâmide, espaço em que normalmente pertenceria.

Dessarte, é de se perceber que o julgamento no Supremo Tribunal Federal não se atentou àquilo que diz a ciência jurídico-penal. Porém, como isso pode ocorrer? A riqueza da construção da hermenêutica jurídica em Kelsen é, sem deixar de lado o princípio metodológico fundamental, e, por conseguinte, o específico papel do jurista científico, dizer que há uma diferença essencial entre o juiz e o cientista, entre o intérprete autêntico e o doutrinário.

0 pressuposto disso é, precisamente, o de que as normas jurídicas não apresentam um sentido único a ser descoberto por quem se aventura pelo mundo do Direito. Muito pelo contrário, há uma pluralidade ou relativa indeterminação de sentido. Essa é a razão pela qual se discute, no caso concreto, a envergadura da norma constitucional quando diz que "a lei punirá qualquer ato atentatório a direitos ou liberdades fundamentais" ${ }^{95}$, e quando a Lei de Racismo dispõe sobre "raça" .

Novamente, o papel da ciência do Direito, em termos kelsenianos, é meramente descritivo, e não político-decisório. Quem decide sobre a envergadura dessa norma é o juiz, o Supremo Tribunal Federal. Mas o juiz não está vinculado às normas ou aos parâmetros

${ }^{91}$ BRASIL. Supremo Tribunal Federal. Ação Direta de Inconstitucionalidade por Omissão $\mathrm{n}^{\circ}$ 26. Partido Popular Socialista. Relator: Ministro Celso de Mello. Disponível em: http://portal.stf.jus.br/processos/detalhe.asp?incidente=4515053. Acesso em: 12 jul. 2019.

92 BRASIL. Supremo Tribunal Federal. Mandado de Injunção 4733. Associação Brasileira de Gays, Lésbicas e Transgêneros - ABGLT. Relator: Ministro Edson Fachin. Disponível em: https: / / portal.stf.jus.br/processos/detalhe.asp?incidente=4239576. Acesso em 13 de jul. de 2019.

${ }_{93}$ BRASIL. Lei $n^{\circ} 7.716 / 89$, de 1989. Define crimes resultantes de preconceito de raça ou de cor. In: Diário Oficial da República Federativa do Brasil, Brasília, DF, 05 jan. 1989. Disponível em: http://www.planalto.gov.br/ccivil_03/leis/l7716.htm. Acesso em: 12 jul. 2019.

94 BRASIL. Constituição Federal. Brasília: Senado Federal, 1988. Disponível em: http:// www.planalto.gov.br/ccivil_03/constituicao/ConstituicaoCompilado.htm. Acesso em: 12 jul. 2019.

95 BRASIL. Constituição Federal. Brasília: Senado Federal, 1988. Disponível em: http://www.planalto.gov.br/ccivil_03/constituicao/ConstituicaoCompilado.htm. Acesso em: 12 jul. 2019.

96 BRASIL. Lei $n^{\circ} 7.716 / 89$, de 1989. Define crimes resultantes de preconceito de raça ou de cor. In: Diário Oficial da República Federativa do Brasil, Brasília, DF, 05 jan. 1989. Disponível em: http://www.planalto.gov.br/ccivil_03/leis/l7716.htm. Acesso em: 12 jul. 2019. 
normativos tais quais apontados pela ciência jurídica? Ou pode ele decidir de um modo completamente fora daquilo que ele estaria, em princípio, vinculado? Porque feita mediante um ato cognoscitivo combinado com um ato volitivo, a atuação do órgão competente não se submete à pureza científica, motivo que faz com que a decisão, seja, no seu âmago, um ato de poder político. Este, inclusive, não adstrito, na prática, à moldura apontada pela ciência.

O que o Supremo Tribunal Federal fez, no caso da criminalização da homofobia e da transfobia, foi decidir fora da moldura, considerando um conceito extremamente amplo de "raça”, o qual não seria comportado pela lei, de acordo com a ciência jurídica. Mas, frise-se, não é que esse julgamento, em particular, foi político; todo e qualquer julgamento, à luz do pensamento de Kelsen, é fundado em ato de vontade, em ato de política jurídica, e não de ciência jurídica. Daí que surge o desafio kelseniano ${ }^{97}$. Ou, ainda, devido à capacidade de decisão fora da moldura, é que há um medo referente à atividade dos juízes, para fazer referência a Eros $\mathrm{Grau}^{98}$, ou à decisão conforme a consciência do julgador, no argumentação de Streck ${ }^{99}$.

Ainda nessa linha de raciocínio, para Posner ${ }^{100}$ seria possível dizer que uma decisão judicial não pode ser explicada sempre a partir de sua conformidade com a lei (legalism). Tal ideia se complementa, por exemplo, a partir de teorias que explicam a decisão judicial em função do posicionamento político do juiz (attitudinal) ou em função de uma análise prévia que o magistrado faz sobre as consequências de eventual decisão (pragmatic). Nas palavras do autor, é por isso que o reino do legalismo se apequenou e que as decisões judiciais não podem mais ser explicadas apenas com base nessa teoria:

Ivan Karamazov disse que se Deus não existe tudo é permitido, e pensadores jurídicos tradicionais provavelmente dizem que se legalismo [...] não existe, tudo é permitido aos juízes - mas cuidado! Legalismo existe, e nem tudo é permitido. Mas seu reino encolheu e se acinzentou ao ponto onde hoje ele é amplamente limitado aos casos de rotina, e então muito é permitido aos juízes ${ }^{101} 102$ (tradução livre).

97 COELHO, Fábio Ulhoa. Para entender Kelsen. São Paulo: Saraiva, 2012. p. 84. FERRAZ JR, Tercio Sampaio. Introdução ao estudo do direito: técnica, decisão, dominação. 8. ed. São Paulo: Atlas, 2015. p. 219.

98 GRAU, Eros Roberto. Por que tenho medo dos juízes: (a interpretação/aplicação do direito e os princípios). 9. ed. refundida do ensaio e discurso sobre a interpretação/aplicação do direito. São Paulo, Malheiros, 2018.

99 STRECK, Lenio Luiz. 0 que é isto - decido conforme minha consciência? 5. ed. Porto Alegre: Livraria do Advogado, 2015.

100 POSNER, Richard A. How judges think. Cambridge, Massachusetts, London: Harvard University Press, 2008.

101 Ivan Karamazov said that if God does not exist everything is permitted, and traditional legal thinkers are likely to say that if legalism (legal formalism, orthodox legal reasoning, a "government of laws not 
De toda sorte, e voltando a Kelsen, no fundo, os juízes não são apenas responsáveis pela aplicação do direito, mas também por sua criação, o que pode se dar por termos completamente ímpares e alheios àqueles descritos pela ciência. Portanto, a hermenêutica jurídica kelseniana se faz sim presente no julgamento da criminalização da homofobia e da transfobia.

\section{CONCLUSÃO}

Assumindo o tema da análise, a partir da hermenêutica jurídica em Kelsen, de julgamentos do Supremo Tribunal Federal, a metodologia empregada foi a pesquisa bibliográfica. O primeiro momento dessa pesquisa se deu com a revisão de literatura nas bases BDTD, SciELO e Portal de Periódicos CAPES, utilizando os descritores, combinados, "Hermenêutica Jurídica", "Hans Kelsen" e "Supremo Tribunal Federal", com o objetivo de se mapear aquilo que se tem escrito a respeito do tema. Cumulativamente, houve, do mesmo modo, o estudo de livros de Hans Kelsen e de seus principais comentadores em âmbito nacional, destacando-se Tercio Sampaio Ferraz Junior e Fábio Ulhoa Coelho.

Diante de todo esse material, foi verificada tanto a magnitude do pensamento de Hans Kelsen, quanto que a pesquisa jurisprudencial e o estudo de casos do Supremo Tribunal Federal é algo necessário para que a ciência jurídica avance. Por isso, o outro momento da metodologia se deu com a análise jurisprudencial, o estudo de caso. Eis a delimitação do objeto de estudo do presente artigo: o caso da criminalização da homofobia e da transfobia foi escolhido por estar entre os mais relevantes e mais atuais.

Então foi possível apontar a problemática desta investigação: há elementos da hermenêutica jurídica em Kelsen no julgamento do Supremo Tribunal Federal acerca da criminalização da homofobia e da transfobia? Para responder tal problema, ao longo do artigo buscou-se expor a hermenêutica jurídica em Kelsen, seguida da exposição sobre o julgamento do Supremo Tribunal Federal. Assim, foi possível estabelecer algumas considerações desse caso à luz da hermenêutica jurídica.

men", the "rule of law" as celebrated in the loftiest Law Day rhetoric, and so forth) does not exist, everything is permitted to judges - so watch out! Legalism does exist, and so not everything is permitted. But its kingdom has shrunk and grayed to the point where today it is largely limited to routine cases, and so a great deal is permitted to judges.

102 POSNER, Richard A. How judges think. Cambridge, Massachusetts, London: Harvard University Press, 2008. p. 1, grifos do autor. 
Por mais que o autor se debruce sobre o pressuposto de uma ciência jurídica neutra, isto é, sobre o princípio metodológico fundamental, ponto pelo qual ele é, atualmente, bastante criticado, não é possível que se desconsidere todo o seu pensamento, muito menos a parte sobre a hermenêutica jurídica. Isso se vê comprovado, inclusive, a partir da revisão de literatura.

Nesta linha, é possível responder que há sim elementos da hermenêutica jurídica kelseniana que explicam o julgamento do Supremo Tribunal Federal sobre a criminalização da homofobia e da transfobia. Kelsen, ao reconhecer a pluralidade de sentidos possíveis a serem fixados para a norma jurídica e ao afirmar que existe uma moldura dentro da qual deve se desenvolver a hermenêutica, também reconhece a diferença existente entre o intérprete autêntico (o órgão competente) e o doutrinário (em especial, a ciência do Direito).

0 primeiro realiza a atividade interpretativa a partir de um ato cognoscitivo combinado com um ato de vontade, sendo o resultado dessa interpretação vinculante e criador de Direito. Já o segundo, especificamente a ciência jurídica, realiza um ato meramente cognoscitivo, atentando-se ao seu objeto de estudo e ao seu princípio metodológico fundamental.

Ocorre que, em se tratando de ato de vontade, há a possibilidade de o intérprete autêntico decidir completamente fora da moldura. É o que ocorreu no caso da ADO 26 e do MI 4733. O Supremo Tribunal Federal, ao afirmar que homofobia e transfobia são termos que podem ser enquadrados dentro de "raça", nos termos da Lei 7.716/89, decidiu fora da moldura, eis que desconsiderou os parâmetros ou molduras normativos apontados pela ciência jurídica, em especial, decidiu na contramão do princípio da legalidade e da taxatividade da lei penal.

Por todos esses motivos, vale sublinhar que, como todo clássico, Hans Kelsen, com todas as suas contribuições e limites à ciência jurídica, deve ser sempre revisitado. Com esse estudo, foi possível perceber que os elementos da hermenêutica jurídica em Kelsen se fazem presentes para a explicação de julgamentos do Supremo Tribunal Federal. Tudo isso só acaba por reafirmar a centralidade da obra de Kelsen, que, entre contribuições e limites, permanece viva no Direito contemporâneo. 


\section{REFERÊNCIAS}

BRASIL. Constituição Federal. Brasília: Senado Federal, 1988. Disponível em:

http://www.planalto.gov.br/ccivil_03/constituicao/ConstituicaoCompilado.htm. Acesso em: 12 jul. 2019.

BRASIL. Decreto Lei $n^{\circ} 2.848 / 40$, de 1940. Código Penal. In: Diário Oficial da República

Federativa do Brasil, Rio de Janeiro, RJ, 07 dez. 1940. Disponível em:

http://www.planalto.gov.br/ccivil_03/decreto-lei/del2848compilado.htm Acesso em: 12 jul.

2019.

BRASIL. Lei $n^{\circ} 7.716 / 89$, de 1989. Define crimes resultantes de preconceito de raça ou de cor.

In: Diário Oficial da República Federativa do Brasil, Brasília, DF, 05 jan. 1989. Disponível em: http://www.planalto.gov.br/ccivil_03/leis//7716.htm. Acesso em: 12 jul. 2019.

BRASIL. Supremo Tribunal Federal. Ação Direta de Inconstitucionalidade por Omissão n 26. Partido Popular Socialista. Relator: Ministro Celso de Mello. Disponível em:

http: / / portal.stf.jus.br/processos/detalhe.asp?incidente=4515053. Acesso em: 12 jul. 2019.

BRASIL. Supremo Tribunal Federal. Acórdão da decisão que permitiu a retificação do nome civil independentemente de cirurgia de transgenitalização. Ação Direta de

Inconstitucionalidade. 4.275. Procuradoria Geral da República. Relator para o acórdão: Ministro Edson Fachin. 07 de março de 2019. Disponível em:

http: //stf.jus.br/portal/jurisprudencia/listarJurisprudencia.asp?s1=\%28ADI\%24\%2ESCLA\%2E+E+42 75\%2ENUME\%2E\%29+OU+\%28ADI\%2EACMS\%2E+ADJ2+4275\%2EACMS\%2E\%29\&base=baseAcordaos\&url =http://tinyurl.com/aju5rhv. Acesso em 12 de jul. de 2019.

BRASIL. Supremo Tribunal Federal. Acórdão da decisão que reconheceu a união homoafetiva. Arguição de Descumprimento de Preceito Fundamental 132. Governador do Estado do Rio de Janeiro. Relator: Ministro Ayres Britto. 05 de maio de 2011. Disponível em:

http: //redir.stf.jus.br/paginadorpub/paginador.jsp?docTP=AC\&docID=628633. Acesso em $12 \mathrm{de}$ jul. de 2019.

BRASIL. Supremo Tribunal Federal. Acórdão da decisão que reconheceu a união homoafetiva Ação Direta de Inconstitucionalidade 4.277. Procuradoria Geral da República. Relator: Ministro Ayres Britto. 05 de maio de 2011. Disponível em:

http: / / redir.stf.jus.br/paginadorpub/paginador.jsp?docTP=AC\&docID=628635. Acesso em 12 de jul. de 2019.

BRASIL. Supremo Tribunal Federal. Acórdão da denegação de Habeas Corpus para a concessão de liberdade ao paciente Siegfried Ellwanger, acusado pelo crime de racismo. Habeas Corpus 82.424/RS. Siegfried Ellwanger Castan. Relator para o acórdão: Ministro Maurício Corrêa. 17 de setembro de 2003. Disponível em:

http://www.stf.jus.br/portal/geral/verPdfPaginado.asp?id=79052\&tipo=AC\&descricao=Inteiro\%2 0Teor\%20HC\%20/\%2082424. Acesso em 12 de jul. de 2019. 
BRASIL. Supremo Tribunal Federal. Mandado de Injunção 4733. Associação Brasileira de Gays, Lésbicas e Transgêneros - ABGLT. Relator: Ministro Edson Fachin. Disponível em: https: //portal.stf.jus.br/processos/detalhe.asp?incidente=4239576. Acesso em 13 de jul. de 2019.

BRASIL. Supremo Tribunal Federal. Voto do Relator, Ministro Celso de Mello. Ação Direta de Inconstitucionalidade por Omissão $n^{\circ} 26$. Partido Popular Socialista. Relator: Ministro Celso de Mello. 20 de fevereiro de 2019. Disponível em: https://www.conjur.com.br/dl/leia-votoministro-celso-mello2.pdf. Acesso em: 12 jul. 2019.

BRASIL. Supremo Tribunal Federal. Voto do Ministro Ricardo Lewandoski. Ação Direta de Inconstitucionalidade por Omissão $\mathrm{n}^{\circ}$ 26. Partido Popular Socialista. Relator: Ministro Celso de Mello. 13 de junho de 2019. Disponível em: https://www.conjur.com.br/dl/legislativo-tipificarcrime-defende.pdf. Acesso em 12 jul. 2019.

CARVALHO, Salo de; DUARTE, Evandro Piza. Criminologia do Preconceito: racismo e homofobia nas Ciências Criminais. São Paulo: Saraiva, 2017.

COELHO, Fábio Ulhoa. Para entender Kelsen. São Paulo: Saraiva, 2012.

FERRAZ JR, Tercio Sampaio. Introdução ao estudo do direito: técnica, decisão, dominação. 8. ed. São Paulo: Atlas, 2015.

GASPAR, Renata Alvares; MENDONÇA, Samuel. O DIPR - Direito Internacional Privado e a Educação Jurídica: um diálogo essencial. Revista Eletrônica do Curso de Direito da UFSM, Santa Maria, RS, v. 13, n. 1, p. 1-19, maio 2018. ISSN 1981-3694. Disponível em: https://periodicos.ufsm.br/revistadireito/article/view/27249. Acesso em: 14 jul. 2019.

GRAU, Eros Roberto. Por que tenho medo dos juízes: (a interpretação/aplicação do direito e os princípios). 9. ed. refundida do ensaio e discurso sobre a interpretação/aplicaçãa do direito. São Paulo, Malheiros, 2018.

KELSEN, Hans. Teoria geral das normas. Porto Alegre: Sergio Fabris, 1986.

KELSEN, Hans. Teoria pura do direito. 6. ed. São Paulo: Martins Fontes, 1998.

KELSEN, Hans. 0 que é a justiça? São Paulo: Martins Fontes, 2001.

MENDONCA, Samuel; ADAID, Felipe Alves Pereira. Tendências teóricas sobre o Ensino Jurídico entre 2004 e 2014: busca pela formação crítica. Rev. Direito GV, São Paulo, v. 14, n. 3, p. 818846, set. 2018. Disponível em http://dx.doi.org/10.1590/2317-6172201831. Acesso em 13 de jul. de 2019.

POSNER, Richard A. How judges think. Cambridge, Massachusetts, London: Harvard University Press, 2008.

SGARBI, Adrian. 0 mundo de Kelsen. São Paulo: Marcial Pons, 2019. 
STRECK, Lenio Luiz. 0 que é isto - decido conforme minha consciência? 5. ed. Porto Alegre: Livraria do Advogado, 2015.

ZAFFARONI, Eugenio Raúl; BATISTA, Nilo. Direito penal brasileiro: teoria geral do direito penal. Rio de Janeiro: Revan, 2003, v. 1.

\section{COMO FAZER REFERÊNCIA AO ARTIGO (ABNT):}

JULIANO, Luiz Felipe M.; MENDONÇA, Samuel. A hermenêutica jurídica em Hans Kelsen e a criminalização da homofobia e da transfobia. Revista Eletrônica do Curso de Direito da UFSM, Santa Maria, RS, v. 15, n. 1, e39078, jan./abr. 2020. ISSN 1981-3694. DOI: http://dx.doi.org/10.5902/1981369439078. Disponível em: https://periodicos.ufsm.br/revistadireito/article/view/39078 Acesso em: dia mês. ano.

Direitos autorais 2020 Revista Eletrônica do Curso de Direito da UFSM

Editores responsáveis: Rafael Santos de Oliveira e Angela Araujo da Silveira Espindola

Esta obra está licenciada com uma Licença Creative Commons Atribuição-NãoComercial-SemDerivações 4.0 Internacional.

\section{SOBRE OS AUTORES}

\section{SAMUEL MENDONÇA}

Professor Titular, vinculado ao Programa de Pós-graduação em Direito, Mestrado Acadêmico, linha de pesquisa Direitos Humanos e Políticas Públicas, grupo de pesquisa Direito e Realidade Social (CNPq/PUC Campinas), ao Programa de PósGraduação em Educação, Mestrado e Doutorado, linha de pesquisa Políticas Públicas em Educação, líder do grupo de pesquisa Política e Fundamentos da Educação (CNPq/PUC Campinas), da Pontifícia Universidade Católica de Campinas. Bolsista Produtividade em pesquisa do Conselho Nacional de Desenvolvimento Científico e Tecnológico (CNPq). Pós-doutorando do Departamento de Economia da Educação da FE-USP, sob a supervisão do Prof. Dr. Romualdo Luiz Portela de Oliveira. Atuou como Visiting Scholar na Shanghai Jiao Ton University, China, em 2014. Desenvolveu atividades como Professor Visitante na PUC Peru, em 2013 e em 2018. Foi professor de Filosofia na Educação Básica, Ensino Fundamental 2 e Ensino Médio, nas redes pública e privada, por 5 anos. Doutor em Filosofia da Educação pela Unicamp, Mestre (área de Ética), Licenciado e Bacharel em Filosofia pela PUC Campinas. Foi Presidente da Associação Latino-americana de Filosofia da Educação (ALFE 2011-2013 e 2013-2015). Foi Secretário da Sociedade Brasileira de Filosofia da Educação (2016-2018). Foi Vice-Coordenador do Forpred Nacional (ANPEd - 2014-2015). Foi Coordenador do Forpred Sudeste (ANPEd - 2013-2014). Foi Coordenador do Programa de Pós-Graduação em Educação da PUC Campinas em 2 mandatos, de 2010 a 2018. Foi Coordenador do Núcleo de Pesquisa e Extensão do Cento de Ciências Humanas e do Centro de Ciências Humanas e Sociais Aplicadas, de 2006 a 2010. Participou de eventos acadêmicos com apresentação de trabalhos ou proferiu conferências em diferentes países, como Estados Unidos da América, China, Etiópia, República Tcheca, Argentina, Uruguai, Colômbia, Peru e México. É Presidente da Sociedade Brasileira de Filosofia da Educação (2018-2020), membro da ABRADE - Associação Brasileira de Direito Educacional, Associado e Avaliador ad hoc do Conselho Nacional de Pesquisa e Pós-Graduação em Direito - CONPEDI e participante de diversas sociedades internacionais: North American Nietzsche Society, PES - Philosophy of Education Society, INPE International Network of Philosophers of Education, ALFE - Asociación Latinoamericana de Filosofía de la Educación. É autor dos livros Aristocratic Education in Nietzsche: individual achievement (Maryland: GlobalSouth, 2018) e Projeto e Monografia Jurídica (Campinas: Millennium, 2009).

\section{LUIZ FELIPE MENDES JULIANO}

Bacharelando em Ciências Sociais e Jurídicas pela Pontifícia Universidade Católica de Campinas e bolsista de Iniciação Científica Pibic/CNPq. Monitor das disciplinas de Introdução ao Estudo do Direito II e de Direitos Humanos II; foi monitor de Introdução ao Estudo do Direito I e de Direitos Humanos I. Integrante do grupo de pesquisa "Direito e Realidade Social" (CNPq/PUC Campinas), do PPG Direito da PUC Campinas. Foi bolsista perante a mesma universidade no Projeto de Extensão que teve como plano de trabalho "Conscientização e desenvolvimento da cidadania", executado no ano de 2017. Estagiário do Ministério Público do Estado de São Paulo. 